\title{
Inhibition of HIV-1 replication by small interfering RNAs directed against Glioma Pathogenesis Related Protein (GliPR) expression
}

\author{
Gianni Capalbo ${ }^{1}$, Thea Müller-Kuller ${ }^{1}$, Ursula Dietrich², Dieter Hoelzer ${ }^{1}$, Oliver G Ottmann ${ }^{1}$, Urban J Scheuring ${ }^{1 *}$
}

\begin{abstract}
Background: Previously, we showed that glioma pathogenesis related protein (GliPR) is induced in CEM T cells upon HIV-1 infection in vitro. To examine whether GliPR plays a role as HIV dependency factor (HDF), we tested the effect of GliPR suppression by siRNA on HIV-1 replication.

Results: Induction of GliPR expression by HIV-1 was confirmed in P4-CCR5 cells. When GliPR was suppressed by siRNA, HIV-1 replication was significantly reduced as measured by HIV-1 transcript levels, HIV-1 p24 protein levels, and HIV-1 LTR-driven reporter gene expression, suggesting that GliPR is a cellular co-factor of HIV-1. Microarray analysis of uninfected HeLa cells following knockdown of GliPR revealed, among a multitude of gene expression alterations, a down-regulation of syndecan-1, syndecan-2, protein kinase $C$ alpha (PRKCA), the catalytic subunit $\beta$ of CAMP-dependent protein kinase (PRKACB), nuclear receptor co-activator 3 (NCOA3), and cell surface protein CD59 (protectin), all genes having relevance for HIV-1 pathology.

Conclusions: The up-regulation of GliPR by HIV-1 and the early significant inhibition of HIV-1 replication mediated by knockdown of GliPR reveal GliPR as an important HIV-1 dependency factor (HDF), which may be exploited for HIV-1 inhibition.
\end{abstract}

\section{Background}

The replication of HIV-1 depends on specific host factors [1-4]. A recent report identified 273 cellular HIV-1 dependency factors (HDF), that are important for HIV-1 replication [5]. Furthermore, HIV-1 modifies the mRNA expression of a relatively large number of host cell genes, as shown by several reports [6-10]. Differential display experiments suggested that the expression of $\sim 700$ host genes (approximately $3 \%$ of all cellular genes) is modified by HIV-1 infection in vitro [9]. A microarray analysis using a limited subset of $1500 \mathrm{cDNAs}$ identified 20 differentially expressed mRNAs from several cellular pathways [7]. Specific HIV-1 proteins including Tat, Nef, gp120 and Vpr were examined to dissect their role in modifying the transcription of cellular genes [11-14]. While some of the differentially expressed cellular genes may play a role in host defense mechanisms, others may

\footnotetext{
* Correspondence: u.scheuring@gmx.de

'Department of Hematology/Oncology and Infectious Diseases, J. W. Goethe-University Hospital, Theodor Stern Kai 7, 60590 Frankfurt/Main, Germany
}

(C) 2010 Capalbo et al; licensee BioMed Central Ltd. This is an Open Access article distributed under the terms of the Creative Commons Attribution License (http://creativecommons.org/licenses/by/2.0), which permits unrestricted use, distribution, and reproduction in any medium, provided the original work is properly cited. facilitate HIV-1 replication, infectivity, species propagation and survival. A subgroup of differential cellular gene expressions may even support both host defense and viral replication, since HIV-1 replication is linked to immune activation of CD4+ T cells. Due to evolutionary selection, HIV-1 is expected to induce specific host factors, favorable for viral replication or propagation, and to suppress unfavorable cellular gene products [15-17]. Therefore, the examination of host cell genes, that are up-regulated upon HIV-1 infection, is expected to identify potential targets for inhibition of HIV-1 replication.

Previously, we found an early up-regulation of GliPR expression by more than 5 -fold in CEM $\mathrm{T}$ cells infected with HIV-1 by a differential display screen [9]. Therefore, we were interested in delineating the role of GliPR for HIV-1 replication.

GliPR was identified originally in human glioblastomas [18] and was also described as related to testes-specific, vespid, and pathogenesis protein 1 (RTVP-1) [19]. Increased expression of GliPR was associated with myelomonocytic differentiation in macrophages [20]. 
Whereas GliPR has been reported to act as a tumor suppressor gene inducing apoptosis in prostate cancer [21-24], it appears to be an oncogene in glioblastomas [25] and Wilms tumors [26]. RTVP-1 protein was reported to contain a $\mathrm{N}$-terminal signal peptide sequence and a transmembrane domain [27]. Furthermore, homology studies revealed a putative active enzymatic center in GliPR [27]. GliPR is homologous to group 1 plant pathogenesis-related proteins (PR-1) that are implicated in plant defense responses to viral, bacterial, and fungal infection $[28,29]$. Since GliPR shows structural similarities with its homologous plant PR-1 proteins, mammalian testis proteins (TPX1) and the insect venom Ag-5 protein, which are secretory proteins $[29,30]$, it has been suspected that GliPR is also secreted. GliPR's homology with plant PR-1 proteins that have been attributed with a defense function may raise the question whether GliPR has an evolutionarily conserved role in innate immune response and human host defense of viral infection including HIV-1. Alternatively or additionally, HIV-1 may induce and exploit GliPR for viral replication.

The effect of GliPR knockdown on HIV-1 replication was studied, in order to test the hypotheses of GliPR being a host defense protein against or a co-factor of HIV-1. Furthermore, in order to identify downstream targets of GliPR, the effect of GliPR suppression on cellular gene expression was also investigated using cDNA microarrays.

\section{Results}

GliPR is induced upon HIV-1 infection in P4-CCR5 cells

Since HIV-1 infection induced GliPR expression in HIV1 infected human $\mathrm{T}$ cell line cells, as described previously [9], we tested whether this modification could be reproduced in P4-CCR5 HeLa cells infected with HIV-1 $1_{\mathrm{LAI}}$. P4-CCR5 HeLa cells were employed for the present study because they are more amenable to efficient transfection of synthetic siRNA compared to lymphocytic cell lines. Quantitative PCR demonstrated an up-regulation of GliPR transcripts by approximately 2 -fold at day 4 after infection compared to uninfected cells (Fig. 1a). In order to display HIV-1 infection kinetics, real-time quantitative PCR was also utilized to determine levels of intracellular HIV-1 viral mRNA normalized by cell number (house keeping gene GAPDH) at different time points following infection (Fig. 1b). The data show that HIV-1 replication is still in the early logarithmic phase at day 4 in this cell culture system and that GliPR expression is induced in this early phase.

\section{Suppression of GliPR mediated by short interfering RNA}

P4-CCR5 cells were transfected with siRNAs specific for GliPR or a non-silencing siRNA, which was 5-prime labeled with rhodamine. Flow cytometry analysis of cells transfected with non-silencing siRNA $24 \mathrm{~h}$ post transfection revealed transfection efficiencies on average of $90 \%$ in all samples. Forty-eight hours after transfection, the relative levels of GliPR mRNA transcripts were decreased by at least $90 \%$, as shown by quantitative realtime PCR (Fig. 2a). Even four and six days after transfection a markedly reduced GliPR expression by at least $80 \%$ compared with non-transfected cells (mock) or cells transfected with non-silencing siRNA was observed (Fig. 2a).

Viability and proliferation rate of P4-CCR5 cells transfected with siRNAs against GliPR or with the
A

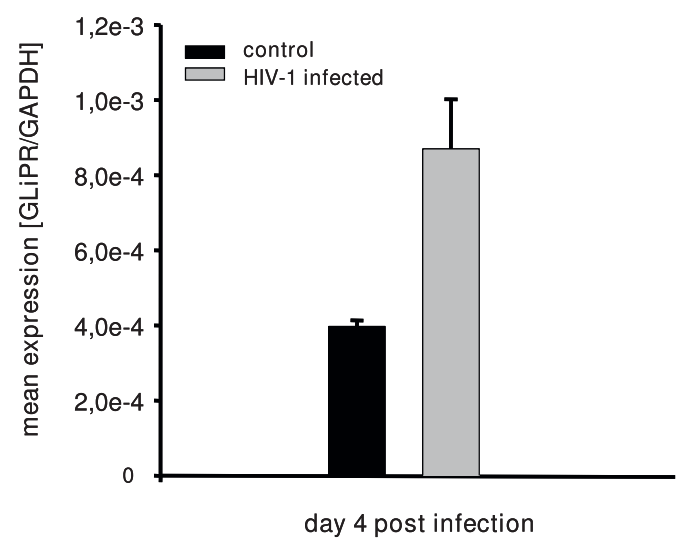

B

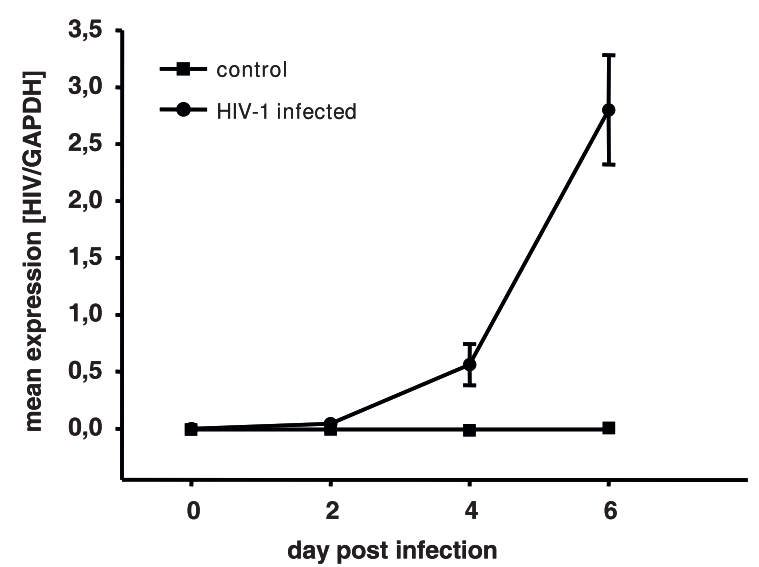

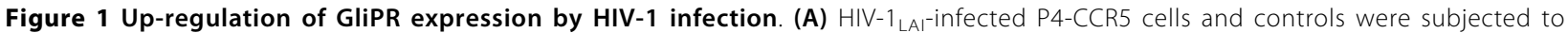
quantitative PCR of GliPR expression at day 4 after HIV-1 infection. (B) In order to display HIV-1 infection kinetics, real-time quantitative PCR was also utilized to determine levels of intracellular HIV-1 viral mRNA normalized by cell number (house keeping gene GAPDH) in triplicate at day 0, 2, 4 and 6 post infection. Bars represent the standard deviation of the mean of determinations. 
non-silencing siRNA remained unchanged as determined by WST-1 cell proliferation assay (Fig. 2b).

In order to establish a test system in a $\mathrm{T}$ cell line as well, a predominant type of host cell for HIV-1, Jurkat cells were transfected with 2 different siRNAs targeting GliPR, control non-silencing siRNA, or mock transfection without any siRNA. GliPR mRNA expression was reduced by around $64 \%$ to $69 \%$ at 48 hours after transfection with specific siRNAs compared to controls (Fig. 2c). The less pronounced reduction of GliPR expression compared to P4-CCR5 HeLa cells may be attributed to the lower transfection efficiency generally observed in $\mathrm{T}$ cell lines. In this experiment, approximately $70 \%$ of Jurkat cells were transfected, while $90 \%$ of P4-CCR5 HeLa cells were transfected.
In general, GliPR-directed siRNAs reduced the expression of GliPR effectively in P4-CCR5 and Jurkat cells without affecting cell viability.

\section{Down-regulation of GliPR by siRNA inhibits HIV-1 replication in P4-CCR5 and Jurkat cells}

In order to examine the effect of GliPR knockdown on HIV-1 replication, P4-CCR5 cells were transfected with GliPR-specific siRNAs and subsequently infected with HIV-1 $1_{\text {LAI }}$. As a negative control, the non-silencing siRNA (si-nons-Rho) was utilized while a siRNA targeting HIV-1 p24 was used as a positive control, since it was able to inhibit viral replication very effectively, as previously demonstrated [31]. HIV-1 infection was performed $24 \mathrm{~h}$ post siRNA transfection with a MOI of
A

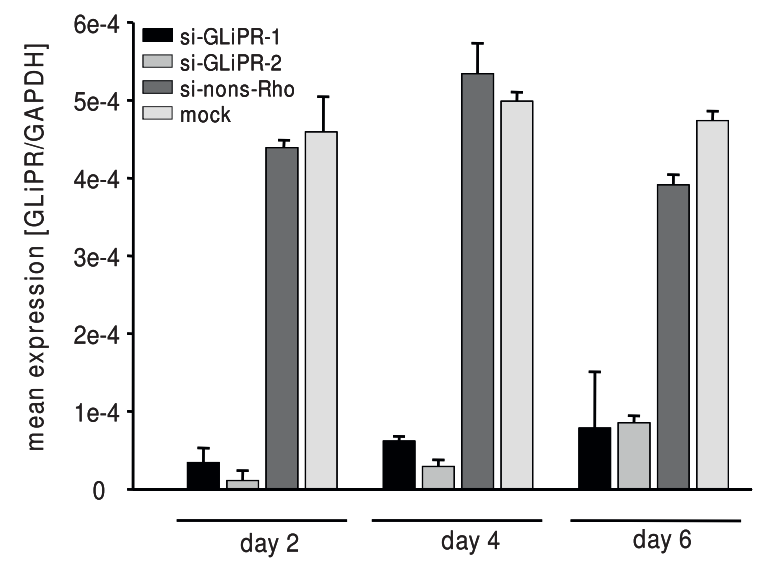

C

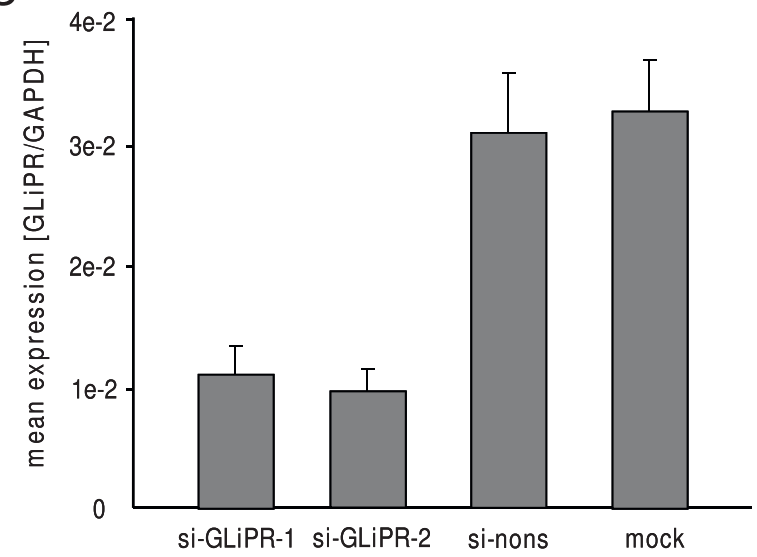

B

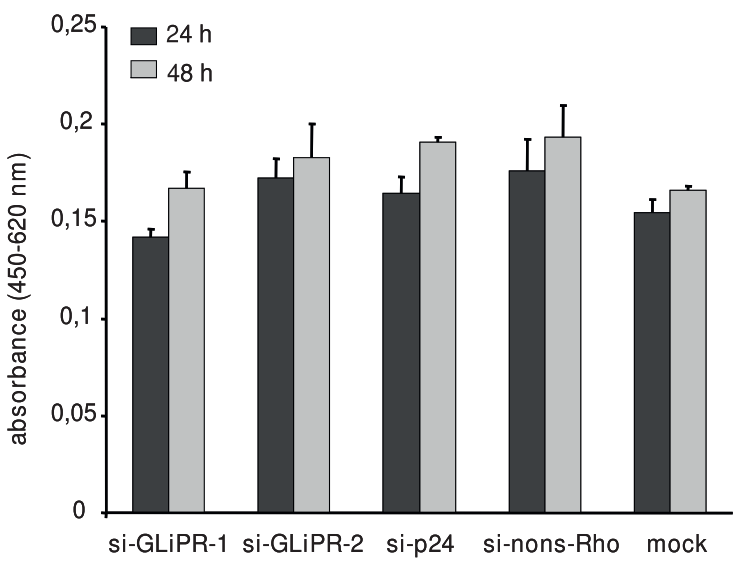

Figure 2 Efficacy of siRNA-mediated suppression of GliPR. (A) Quantitative PCR analysis of GliPR expression in P4-CCR5 cells which were transfected with 2 different siRNAs against GliPR or the control non-silencing siRNA labeled with rhodamine. Results are presented as mean values of triplicate samples \pm standard deviation (SD). (B) Cell viability was determined with the WST-1 assay $24 \mathrm{~h}$ and $48 \mathrm{~h}$ after siRNA transfection. Results are expressed as absorbance $\left(\mathrm{OD}_{450}\right)$. Bars represent the standard deviation of the mean of determinations. (C) Quantitative PCR analysis of GliPR expression in Jurkat cells 2 days after transfection with 2 different siRNAs against GliPR or the control non-silencing siRNA labeled with rhodamine. 
0.01 or 0.05 . Sequential cell-associated HIV-1 viral mRNA levels were determined by real-time quantitative PCR during 6 days after infection. As expected, the positive control siRNA (si-p24) exhibited a marked inhibition in viral mRNA transcription. Similarly, the siRNA-mediated reduction of GliPR expression was followed by significantly reduced viral mRNA transcript levels compared to HIV-1 infected controls, which were mock-transfected (mock) or transfected with the nonsilencing siRNA (si-nons-Rho) at both MOI of 0.01 and 0.05 (Fig. 3a and 3b).

The effect of GliPR suppression on HIV-1 replication was confirmed by p24 ELISA, showing a significantly reduced p24 expression at day 4 post infection in cultures with GliPR knock-down compared to controls with non-silencing siRNA (Fig. 3c).

In order to test this phenomenon in $\mathrm{T}$ cells, Jurkat cells transfected with siRNAs specific to GliPR or control siRNA were infected with HIV-1 at a MOI of 0.01 . GliPR-specific siRNAs resulted in a significant reduction of HIV-1 replication, similar to the positive control with siRNA against p24 (Fig 3d). Thus the $\mathrm{T}$ cell line results are in line with the data in P4-CCR5 cells.

Furthermore, the effect on HIV-1 replication was examined by the integrated HIV-1-LTR-driven reporter vector expressing $\beta$-galactosidase in P4-CCR5 cells.

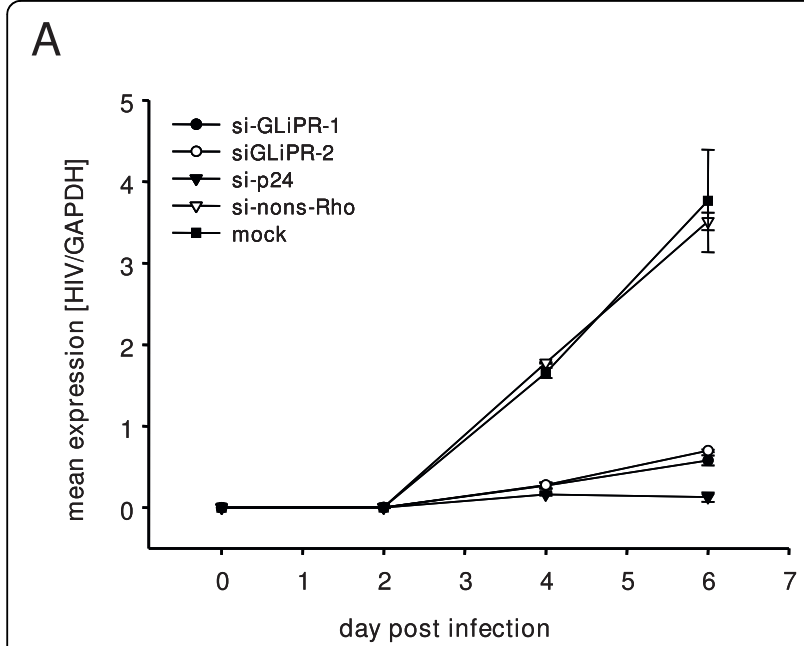

B

C
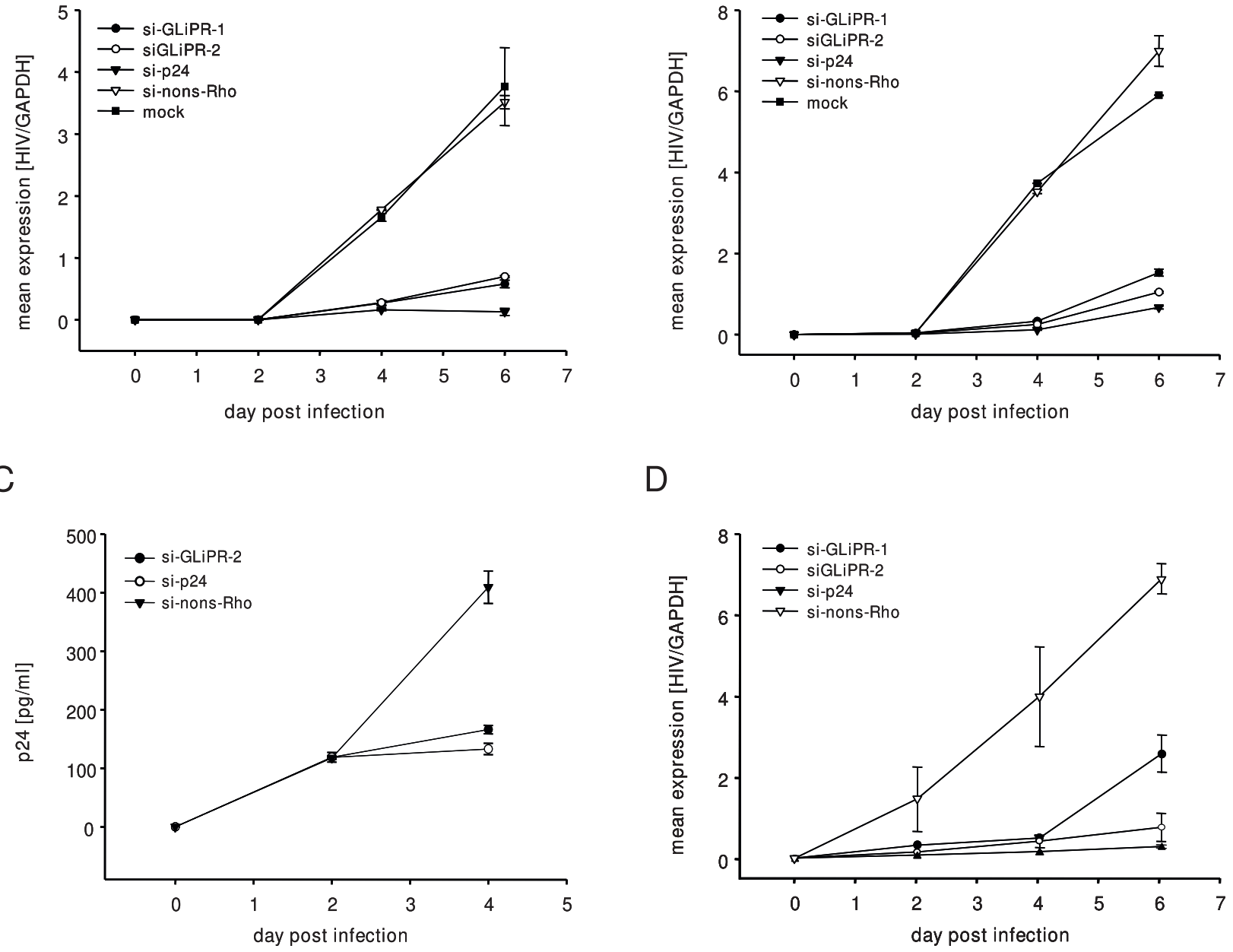

Figure 3 Effects of siRNA transfections on HIV-1 replication. P4-CCR5 cells were transfected with siRNAs directed against GliPR, viral p24 or an unspecific sequence (non-silencing control) and subsequently infected with HIV-1 LAI with a multiplicity of infection of 0.01 (A) and 0.05 (B), respectively. HIV-1 RNA copy numbers were normalized per cell count by house keeping gene GAPDH. (C) P4-CCR5 cells were transfected with siGliPR-2, si-p24 or non-silencing control siRNA and subsequently infected with HIV-1 LAI with a multiplicity of infection of 0.01. Concentrations of viral p24 at day 0, 2 and 4 represent mean values of triplicate samples. (D) Jurkat cells were transfected with siRNAs directed against GliPR, viral p24 or an unspecific sequence (non-silencing control) and subsequently infected with HIV-1 LAI with a multiplicity of infection 0.01. HIV-1 RNA copy numbers were normalized per cell count by house keeping gene GAPDH. 
HIV-1 Tat-mediated transactivation of the LTR leads to expression of measurable $\beta$-galactosidase activity, allowing measurments of inhibitory effects on HIV-1 replication as reductions in $\beta$-galactosidase activity. The expression of $\beta$-galactosidase was markedly decreased by siGliPR on day four after infection, comparable to the degree of the positive control with p24 siRNA (Fig. 4a). The inhibition of LTR-driven transcription was confirmed by microscopy of these cell cultures after $\mathrm{X}$-Gal staining on day six after infection (Fig. 4b).

These results demonstrated that siRNA-mediated suppression of GliPR inhibited HIV-1 replication implicating that GliPR promotes HIV-1 replication. It was not possible to employ the opposite approach by assessing the effect of GliPR's over-expression on HIV-1 replication, since forced expression of GliPR caused rapid

A

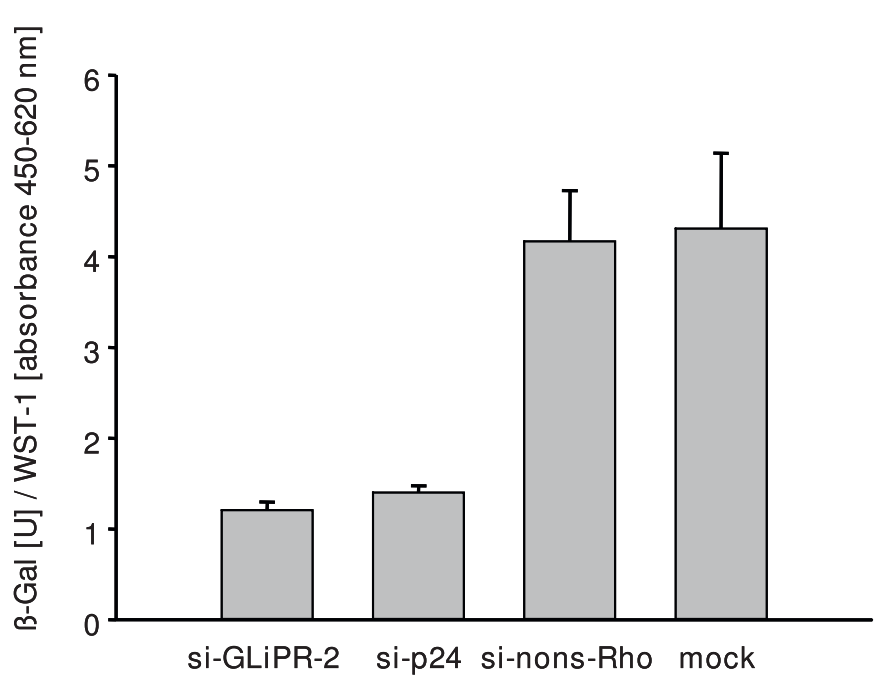

B
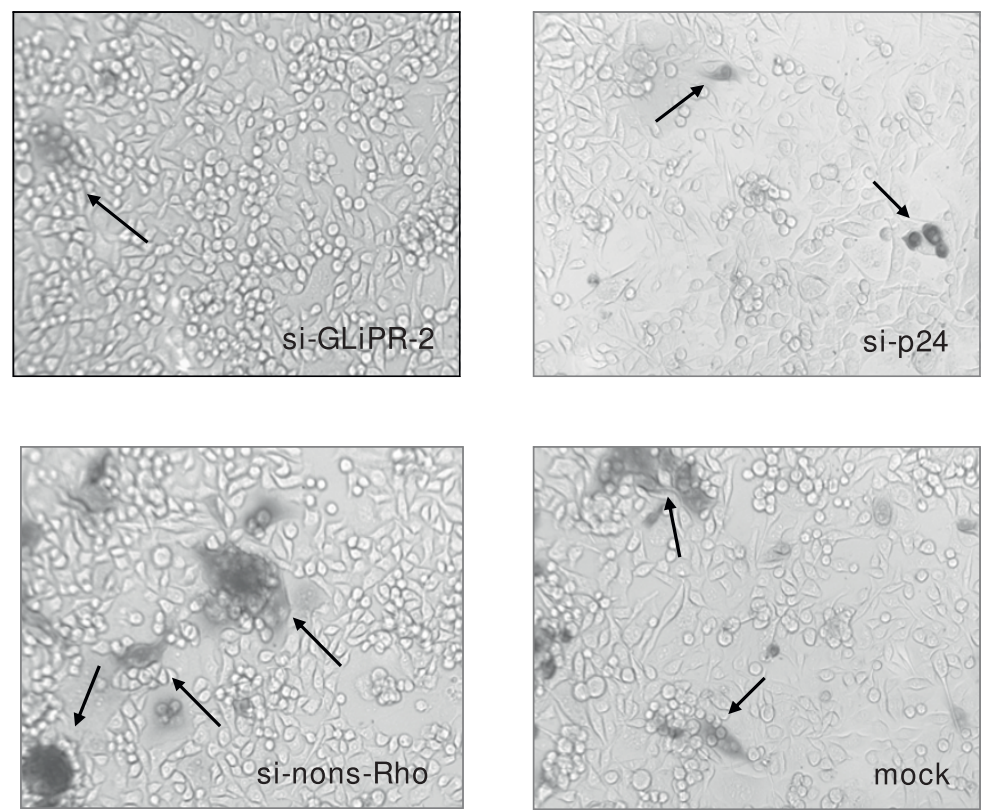

Figure 4 Expression of $\boldsymbol{\beta}$-galactosidase driven by HIV-1-LTR in HIV-infected cells after siRNA transfection. P4-CCR5 cells containing a HIV1-LTR driven $\beta$-galactosidase reporter vector were transfected with siGliPR-2, non-silencing control siRNA or no siRNA (mock) and subsequently infected with HIV-1 $1_{\text {LAI }}$ with a multiplicity of infection of 0.01 . (A) $\beta$-galactosidase units at day 4 normalized by relative WST-1 values represent mean values from triplicate samples. (B) Photomicrograph of $\beta$-gal stained P4-CCR5 cells infected with HIV-1 LAl (MOI 0.01) after transfection with mock, GliPR-siRNA, HIV-1 p24-siRNA or non-silencing control siRNA at day 6 post infection. 
induction of apoptosis in HeLa cells and Jurkat cells (unpublished data).

\section{Differentially expressed genes after GliPR suppression with relevance for HIV-1 replication}

In order to examine the effect of GliPR knock-down on cellular gene expression, microarray analyses were performed to identify cellular target genes of GliPR involved in HIV-1 pathology. The list of genes differentially expressed in uninfected HeLa cells following suppression of GliPR was screened for those genes which had been reported in the context of HIV-1 infection previously. Six genes with potential role in HIV-1 pathology were identified within the list of genes $(n=$ 262) that were differentially regulated after GliPR suppression (Table 1).

\section{Discussion}

The present investigation confirmed the up-regulation of GliPR induced by HIV-1 infection that we had found in a lymphocytic cell line [9] in P4-CCR5 HeLa cells. The suppression of GliPR expression by siRNA was associated with a significant inhibition of HIV-1 replication compared to controls as determined by quantitative PCR for HIV-1 transcripts, p24 ELISA, and HIV-1 LTR driven $\beta$-galactosidase expression. The inhibition of HIV-1 transcription following knockdown of GliPR was confirmed in Jurkat $\mathrm{T}$ cells. Furthermore, the knockdown of GliPR in uninfected HeLa cells revealed 6 differentially expressed genes, which had been reported to be associated with HIV-1 pathology.

The first hypothesis that GliPR induction is a cellular defense reaction hindering HIV-1 replication has to be questioned. If GliPR had exerted an anti-viral effect against HIV-1, the suppression of GliPR would have been expected to show an enhancing effect on HIV-1 replication, which was not found to be the case.

The second hypothesis that GliPR acts as a HIV-1 cofactor has to be favored, since down-regulation of GliPR expression caused a significant inhibition of HIV-1 replication, implying that GliPR promotes HIV-1 replication. This result could not be corroborated by the inverse technique of over-expressing GliPR because over-expression of GliPR caused apoptosis as reported for prostate cancer cell lines [22] and confirmed by us for HeLa and Jurkat cells (unpublished data). Apoptosis would have disguised a putative promoting effect on HIV-1 replication, since apoptosis per se would have affected the kinetics of HIV-1 replication.

The initiation of apoptosis in an infected cell may be considered to be an ancient defense mechanism aimed at the abortion of infection for the organism. Apparently, HIV-1 escapes this putative mechanism of defense as long as its replication has not been completed by blocking apoptosis initially via up-regulation of bcl-2 via Tat [32-34] or by other mechanisms, e.g. reduction of Bax or inhibition of ISG15 [35,36].

Moreover, HIV-1 appears to exploit a specific function of GliPR or GliPR-induced gene products for its replication. Therefore, GliPR may be considered as an HDF [1-4]. A recent report identified $237 \mathrm{HDF}$ in a broad siRNA screen, in addition to 36 already described HDF [5]. GliPR was not found by this HDF screen, although our results suggest that it meets the criteria for an HDF. Apparently the detection of HDF depends on the specific experimental conditions and the selection criteria set for sensitivity and specificity of a screening approach.

It has been shown that tumor suppressor protein p53 is a direct transcriptional activator of GliPR. GliPR may also be induced independently of p53 [22]. It has been reported that HIV-1 induces or activates p53 [37,38], suggesting a p53-mediated pathway for up-regulation of GliPR by HIV-1.

It is also of interest to understand the mechanism by which GliPR promotes HIV-1 replication. The modeling of GliPR's protein structure revealed an active site [27]. Protein Tex31, which is a member of the PR-1 protein family and a component of the cone snail venom, is a substrate specific protease [39]. Golgi associated PR-1 related protein-1 (GAPR-1) also called GliPR2 due to its

Table 1 Differentially expressed genes in siGliPR transfected HeLa cells relevant to HIV-1 pathology.

\begin{tabular}{llcc}
\hline Probe Set ID & Gene Title & Gene Symbol & fold change \\
\hline 201286_at & syndecan 1 & SDC1 & -3.37 \\
202741_at & protein kinase, cAMP-dependent, catalytic $\beta$ & PRKACB & -3.52 \\
207700_at & nuclear receptor coactivator 3 & NCOA3 & -6.53 \\
212154_at & syndecan 2 (heparan sulfate proteoglycan) & SDC2 & -3.05 \\
212157_at & & & -20.23 \\
212158_at & CD59 antigen p18-20 & CD59 & -16.54 \\
212463_at & protein kinase C, alpha & PRKCA & -3.11 \\
213093_at & & & -3.55 \\
215195_at & & -4.09 \\
\hline
\end{tabular}

Cellular genes that were found $>3$-fold induced $(+)$ or suppressed $(-)$ by siGliPR transfection of uninfected HeLa cells are listed with the factor of induction or suppression. Only genes that appeared to be relevant for HIV-1 infection according to a PubMed literature screen are listed. 
close homology with GliPR, is a putative serine protease, too [40]. It may be hypothesized that a potential GliPR protease activity may be involved in the processing of a specific HIV-1 protein as it has been demonstrated for other cellular proteases such as furin and $\mathrm{PC} 7$ in processing of gp160 [41]. The interaction of GliPR with HIV-1 polypeptides is possible since GliPR is localized in the endoplasmic reticulum (unpublished data).

Our microarray screen found 6 gene products downregulated by GliPR suppression that have been reported in the context of HIV:

Syndecan-1 and syndecan-2 are heparansulfate proteoglycans and membrane proteins involved in cellular proliferation, migration and matrix interactions. Syndecan-1 functions as receptor for internalizing extracellular Tat protein [42] and syndecan-2 as regulator of $\mathrm{T}$ cell activation [43].

The catalytic subunit $\beta$ of cAMP-dependent protein kinase (PRKACB) phosphorylates HIV-1 precursor protein and matrix protein p17 thereby initiating their translocation [44]. PRKACB is incorporated in HIV-1 virions and regulates viral infectivity [45]. PRKCA phosphorylates Tat and transactivates HIV-1-LTR [46].

The nuclear receptor coactivator 3 (NCOA3) interacts with Tat enhancing Tat's transactivating effect [47].

The cell surface protein CD59 (protectin) prevents the formation of membrane attack complexes (MAC). CD59 co-localizes with HIV-1 matrix protein p17 in virions [48].

\section{Conclusions}

GliPR is induced in early HIV-1 infection in vitro. According to the profound inhibitory effect of GliPR knock-down on HIV-1 replication, GliPR is an important HDF. Future research needs to address whether GliPR directly functions as a co-factor of HIV-1 processing or whether it exerts its effect via other cellular target genes as identified by our microarray screen. It is also important to define the role of GliPR in cellular defense against other viral infections in general.

\section{Methods}

\section{Cell culture and HIV-1 infection}

For siRNA knock-down experiments, HeLa cells and P4CCR5 [49] cells (HeLa CD4 ${ }^{+} \mathrm{CCR}^{+}$long terminal repeat-LacZ) were cultured in Dulbecco's modified Eagle's medium (Invitrogen, Karlsruhe, Germany). C8166 and Jurkat cells were cultured in RPMI 1640 medium (Invitrogen). All media were supplemented with $10 \%$ fetal calf serum (Gibco-BRL, Karlsruhe, Germany), $1 \%$ glutamine (Gibco-BRL) and $1 \%$ antibiotic solution (penicillin and streptomycin; Gibco-BRL). P4CCR5 cells were cultured in the presence of $100 \mu \mathrm{g} / \mathrm{ml}$ G418 (PAA Laboratories, Coelbe, Germany) and $1 \mu \mathrm{g} /$ ml Puromycin (PAA Laboratories). Transfection and infection of the cells were carried out in the absence of any antibiotics. The HIV-1 strain LAI was taken from the supernatant fluid of freshly infected H9 cells. Viral titer $\left(\mathrm{TCID}_{50}\right.$ units $\left./ \mathrm{ml}\right)$ was determined by titration on C8166 cells as described [50].

$24 \mathrm{~h}$ after siRNA transfection, P4-CCR5 or Jurkat cells were infected with HIV-1 $1_{\text {LAI }}$ in triplicate at a multiplicity of infection (MOI) of 0.01 or 0.05 . Infection of P4CCR5 cells was carried out in the presence of $50 \mu \mathrm{g} / \mathrm{ml}$ DEAE-Dextran (Sigma, Taufkirchen, Germany). After incubation for $4 \mathrm{~h}$ the cells were washed with PBS and re-fed with fresh medium. Cells and supernatant samples were collected for quantitative PCR analysis, $\beta$ galactosidase enzyme assay and HIV-1 p24 antigen ELISA at indicated time points.

\section{siRNA transfection}

siRNAs with the following sequences were used: a positive control siRNA against HIV-1 p24 [31], (si-p24: 5'-GAU UGU ACU GAG AGA CAG Gdtdt-3'); a negative control non-silencing siRNA with no known homology to mammalian genes (si-nons-Rho: 5'-UUC UCC GAA CGU GUC ACG Udtdt-3'; 5-prime labeled with rhodamine); and two different siRNAs specific to GliPR (si-GliPR-1: 5'-GGU GAA ACC AAC AGC CAG Udtdt-3'; si-GliPR-2: 5'-GGA CUA UGA CUU CAA GAC Udtdt-3'). All siRNAs were synthesized by Ambion (Darmstadt, Germany) and were purchased as annealed RNA-duplexes. $24 \mathrm{~h}$ before transfection, HeLa or P4-CCR5 cells were plated in 24-well plates (Corning, Kaiserslautern, Germany) at $5 \times 10^{4}$ cells per well in Dulbecco's minimal essential medium containing 10\% FBS with no antibiotics. Transfections were performed with Lipofectamine 2000 transfection reagent (Invitrogen) with siRNA at a final concentration of $20 \mathrm{nM}$ according to the manufacturer's recommendations. After incubating for $6 \mathrm{~h}$, the lipid/siRNA complexes were removed and replaced with fresh medium. For further analysis, cells were removed from the culture dish by trypsinization with $0.25 \%$ trypsin $/ 0.02 \%$ EDTA in PBS (Cambrex, Verviers, Belgium) at different time points after transfection. Transfection of Jurkat cells was performed with HiPerFect Transfection Reagent (Qiagen, Hilden, Germany) with siRNA at a final concentration of $100 \mathrm{nM}$ according to the manufacturer's recommendations. Transfection efficiency was analyzed by flow cytometry $24 \mathrm{~h}$ after transfection. Data were acquired and analyzed on FACScan with Cell Quest software (Becton Dickinson, Heidelberg, Germany). Effects on cellular viability after siRNA treatment were measured using the cell proliferation reagent WST-1 according to the manufacturer's instructions (Roche, Penzberg, Germany). 
Real time PCR quantification of viral and cellular RNA RNA was extracted using the RNeasy mini kit (Invitrogen) including treatment with RNase-free DNase I (Qiagen). Synthesis of cDNA was carried out using random hexamer primers and Superscript-II RNaseH-reverse transcriptase according to the manufacturer's specifications (Invitrogen).

Real-time PCR was performed in duplicate reactions employing ABI PRISM 7700 (Applied Biosystems, Darmstadt, Germany) with standard conditions $\left(50^{\circ} \mathrm{C}\right.$ for $2 \mathrm{~min}, 95^{\circ} \mathrm{C}$ for $10 \mathrm{~min}$ and 40 cycles at $95^{\circ} \mathrm{C}$ for 15 $\mathrm{s}$ and $60^{\circ} \mathrm{C}$ for $1 \mathrm{~min}$ ). The $25 \mu \mathrm{lPCR}$ included $2,5 \mu \mathrm{l}$ cDNA, 1× TaqMan ${ }^{\circ}$ Universal PCR Master Mix (Applied Biosystems), $0.2 \mu \mathrm{M}$ TaqMan ${ }^{\circ}$ probe, $0.2 \mu \mathrm{M}$ forward primer and $0.2 \mu \mathrm{M}$ reverse primer. Primers and probes were designed using Primer Express v.1.0 software (Applied Biosystems) and were synthesized by Thermohybaid (Ulm, Germany). In order to quantify GliPR, HIV-pol and GAPDH cDNA, the following primers and probes were used: GliPR (sense: 5'-TGC CAG ACA AAG CAT GCG T-3'; antisense: 5'-GCT GTG TGT GAA TAA TTG GAG ACA A-3'; probe: 5'-FAMTCA CAC TTG CTA CAA TAG CCT GGA TGG TTT C-3'-TAMRA), HIV-pol (sense: 5'-AAT TTC ACC AGT ACT ACG GTT AAG GC-3'; antisense: 5'-CTT TAA TTC TTT ATT CAT AGA TTC TAC TAC TCC TTG3'; probe: 5'-FAM-TGT TGG TGG GCG GGA ATC AAG C-3'-TAMRA) and GAPDH (sense: 5'-GAA GGT GAA GGT CGG AGT C-3'; antisense: 5'-GAA GAT GGT GAT GGG ATT TC-3'; probe: 5'-FAM-CAA GCT TCC CGT TCT CAG CC-3'-TAMRA). The probes were labeled with FAM at the 5' end and TAMRA at the 3' end. Copy numbers of the respective transcripts were calculated by plasmid standard curves, normalized by GAPDH housekeeping gene transcripts. Standard curves were obtained after amplification of log step dilutions between 10 to $10^{6}$ copy numbers of purified plasmids carrying the amplicons of GliPR, HIV-1-pol (modified plasmid pLAI.2 obtained from the NIH AIDS Research \& Reference Reagent Program) or human GAPDH [51], respectively. The plasmid standard for the quantification of GliPR was prepared by inserting a PCR-generated fragment (sense: 5'-GGA TCC ATG CGT GTC ACA CTT GCT ACA ATA GC-3' and antisense: 5'-GTC GAC TTA GTC CAA AAG AAC TAA ATT AGG GTA CTT GAG C-3') into pCR2.1 (Invitrogen), which was amplified using HeLa cDNA as template.

\section{$\beta$-Gal staining of cells}

At indicated time points after HIV-1 $1_{\mathrm{LAI}}$ infection, P4CCR5 cells were washed twice with PBS and fixed for 5 $\mathrm{min}$ in fixative $(0.25 \%$ glutaraldehyde in PBS) at room temperature. After two washes with PBS, cells were covered with staining solution (PBS containing $4 \mathrm{mM}$ potassium ferrocyanide, $4 \mathrm{mM}$ potassium ferricyanide, 2 $\mathrm{mM} \mathrm{MgCl}_{2}$, and $0.4 \mathrm{mg} / \mathrm{ml}$ of X-Gal [5-bromo-4chloro-3-indolyl- $\beta$-D-galactopyranoside]) and incubated at $37^{\circ} \mathrm{C}$. Subsequently plates were washed twice with PBS and numbers of $\beta$-Gal-positive (blue) cells were examined microscopically.

\section{$\beta$-galactosidase enzyme assay}

Cell lysates were prepared by using Reporter Lysis Buffer (Promega, Mannheim, Germany). To perform 96well plate $\beta$-galactosidase assays $50 \mu \mathrm{l}$ of cell lysates and $50 \mu \mathrm{l}$ of $2 \times \beta$-galactosidase assay buffer (Promega) were mixed and incubated at $37^{\circ} \mathrm{C}$ for $30 \mathrm{~min}$. To stop the reaction, $150 \mu \mathrm{l}$ of $1 \mathrm{M}$ sodium carbonate was added to the mixture and mixed well by vortexing briefly. Absorbance of the reaction mixture was read immediately at $420 \mathrm{~nm}$. A standard curve was created, using standards between 0 and $6.0 \times 10^{-3}$ units of Galactosidase (Promega). Reporter assay results were normalized according to relative cell numbers, which were estimated by using the cell proliferation reagent WST-1 according to the manufacturer's instructions (Roche).

\section{HIV-1 p24 antigen ELISA}

HIV-1 p24 ELISA was performed using a commercially available kit (Beckmann Coulter, Krefeld, Germany) according to the manufacturer's instructions. For measuring p24 in the supernatants, 100-fold dilutions of the supernatants were used. All ELISA measurements were done in triplicate.

\section{Gene expression analysis by microarrays}

The microarray analysis of the effect of GliPR suppression by siRNA was performed using the HG-U133 Plus 2.0 microarray of Affymetrix (Santa Clara, CA USA) per manufacturer's instructions (GeneChip Expression Analysis Manual). This chip contains 47,000 transcripts which represent 39,000 annotated genes. The data analysis was carried out according to established standards for Affymetric microarrays using GeneChip Operating Software (GCOS; Affymetrix) and GeneSpring (Agilent Technologies).

\section{Acknowledgements}

We are very grateful to Sandra Markovic for excellent technical assistance. We are very grateful to the H. W. \& J. Hector Stiftung (foundation), Mannheim, Germany that provided a grant to support this research.

\section{Author details}

'Department of Hematology/Oncology and Infectious Diseases, J. W. Goethe-University Hospital, Theodor Stern Kai 7, 60590 Frankfurt/Main, Germany. ${ }^{2}$ Georg-Speyer-Haus, Institute for Biomedical Research, Paul-EhrlichStr. 42-44, 60596 Frankfurt/Main, Germany. 


\section{Authors' contributions}

GC performed the experiments and contributed to draft the manuscript. TMK contributed to the experiments and to the analysis of data. $\mathrm{DH}$, UD and OGO participated in the design of the study and helped to draft the manuscript. UJS directed the work and completed the manuscript. All authors read and approved the final manuscript.

\section{Competing interests}

The authors declare that they have no competing interests.

Received: 22 August 2008 Accepted: 31 March 2010 Published: 31 March 2010

\section{References}

1. Agbottah ET, Traviss C, McArdle J, Karki S, St Laurent GC, Kumar A: Nuclea Factor 90(NF90) targeted to TAR RNA inhibits transcriptional activation of HIV-1. Retrovirology 2007, 4:41.

2. Lama J, Planelles V: Host factors influencing susceptibility to HIV infection and AIDS progression. Retrovirology 2007, 4:52.

3. Vardabasso C, Manganaro L, Lusic M, Marcello A, Giacca M: The histone chaperone protein Nucleosome Assembly Protein-1 (hNAP-1) binds HIV1 Tat and promotes viral transcription. Retrovirology 2008, 5:8.

4. Ye Y, De Leon J, Yokoyama N, Naidu Y, Camerini D: DBR1 siRNA inhibition of HIV-1 replication. Retrovirology 2005, 2:63.

5. Brass AL, Dykxhoorn DM, Benita Y, Yan N, Engelman A, Xavier RJ, Lieberman J, Elledge SJ: Identification of host proteins required for HIV infection through a functional genomic screen. Science 2008, 319:921-926.

6. Bosinger SE, Hosiawa KA, Cameron MJ, Persad D, Ran L, Xu L, Boulassel MR, Parenteau M, Fournier J, Rud EW, Kelvin DJ: Gene expression profiling of host response in models of acute HIV infection. J Immunol 2004, 173:6858-6863.

7. Geiss GK, Bumgarner RE, An MC, Agy MB, van 't Wout AB, Hammersmark E, Carter VS, Upchurch D, Mullins Jl, Katze MG: Large-scale monitoring of host cell gene expression during HIV-1 infection using CDNA microarrays. Virology 2000, 266:8-16.

8. Krishnan V, Zeichner SL: Host cell gene expression during human immunodeficiency virus type 1 latency and reactivation and effects of targeting genes that are differentially expressed in viral latency. J Virol 2004, 78:9458-9473.

9. Scheuring UJ, Corbeil J, Mosier DE, Theofilopoulos AN: Early modification of host cell gene expression induced by HIV-1. Aids 1998, 12:563-570.

10. Yin J, Chen MF, Finkel TH: Differential gene expression during HIV-1 infection analyzed by suppression subtractive hybridization. Aids 2004, 18:587-596.

11. Cicala C, Arthos J, Selig SM, Dennis G Jr, Hosack DA, Van Ryk D, Spangler ML, Steenbeke TD, Khazanie P, Gupta N, Yang J, Daucher M, Lempicki RA, Fauci AS: HIV envelope induces a cascade of cell signals in non-proliferating target cells that favor virus replication. Proc Natl Acad Sci USA 2002, 99:9380-9385.

12. de la Fuente C, Santiago F, Deng L, Eadie C, Zilberman I, Kehn K, Maddukuri A, Baylor S, Wu K, Lee CG, Pumfery A, Kashanchi F: Gene expression profile of HIV-1 Tat expressing cells: a close interplay between proliferative and differentiation signals. BMC Biochem 2002, 3:14.

13. Janket ML, Manickam P, Majumder B, Thotala D, Wagner M, Schafer EA, Collman RG, Srinivasan A, Ayyavoo V: Differential regulation of host cellular genes by HIV-1 viral protein R (Vpr): CDNA microarray analysis using isogenic virus. Biochem Biophys Res Commun 2004, 314:1126-1132.

14. Joseph AM, Kumar M, Mitra D: Nef: "necessary and enforcing factor" in HIV infection. Curr HIV Res 2005, 3:87-94.

15. Goff SP: Genetic control of retrovirus susceptibility in mammalian cells. Annu Rev Genet 2004, 38:61-85.

16. Komano J, Futahashi Y, Urano E, Miyauchi K, Murakami T, Matsuda Z, Yamamoto N: The interaction of HIV-1 with the host factors. Jpn J Infect Dis 2005, 58:125-130.

17. Wahl SM, Greenwell-Wild T, Vazquez N: HIV accomplices and adversaries in macrophage infection. J Leukoc Bio/ 2006, 80:973-983.

18. Murphy EV, Zhang Y, Zhu W, Biggs J: The human glioma pathogenesisrelated protein is structurally related to plant pathogenesis-related proteins and its gene is expressed specifically in brain tumors. Gene 1995, 159:131-135.
19. Rich T, Chen P, Furman F, Huynh N, Israel MA: RTVP-1, a novel human gene with sequence similarity to genes of diverse species, is expressed in tumor cell lines of glial but not neuronal origin. Gene 1996, 180:125-130.

20. Gingras MC, Margolin JF: Differential expression of multiple unexpected genes during U937 cell and macrophage differentiation detected by suppressive subtractive hybridization. Exp Hematol 2000, 28:65-76.

21. Naruishi K, Timme TL, Kusaka N, Fujita T, Yang G, Goltsov A, Satoh T, Ji X, Tian W, Abdelfattah E, Men T, Watanabe M, Tabata K, Thompson TC: Adenoviral vector-mediated RTVP-1 gene-modified tumor cell-based vaccine suppresses the development of experimental prostate cancer. Cancer Gene Ther 2006, 13:658-663.

22. Ren C, Li L, Goltsov AA, Timme TL, Tahir SA, Wang J, Garza L, Chinault AC, Thompson TC: mRTVP-1, a novel p53 target gene with proapoptotic activities. Mol Cell Biol 2002, 22:3345-3357.

23. Ren C, Li L, Yang G, Timme TL, Goltsov A, Ren C, Ji X, Addai J, Luo H, Ittmann MM, Thompson TC: RTVP-1, a tumor suppressor inactivated by methylation in prostate cancer. Cancer Res 2004, 64:969-976.

24. Satoh T, Timme TL, Saika T, Ebara S, Yang G, Wang J, Ren C, Kusaka N, Mouraviev V, Thompson TC: Adenoviral vector-mediated mRTVP-1 gene therapy for prostate cancer. Hum Gene Ther 2003, 14:91-101.

25. Rosenzweig T, Ziv-Av A, Xiang C, Lu W, Cazacu S, Taler D, Miller CG, Reich R, Shoshan Y, Anikster Y, Kazimirsky G, Sarid R, Brodie C: Related to testes-specific, vespid, and pathogenesis protein-1 (RTVP-1) is overexpressed in gliomas and regulates the growth, survival, and invasion of glioma cells. Cancer Res 2006, 66:4139-4148.

26. Chilukamarri L, Hancock AL, Malik S, Zabkiewicz J, Baker JA, Greenhough A, Dallosso AR, Huang TH, Royer-Pokora B, Brown KW, Malik K: Hypomethylation and aberrant expression of the glioma pathogenesisrelated 1 gene in Wilms tumors. Neoplasia 2007, 9:970-978.

27. Szyperski T, Fernandez C, Mumenthaler C, Wuthrich K: Structure comparison of human glioma pathogenesis-related protein GliPR and the plant pathogenesis-related protein P14a indicates a functional link between the human immune system and a plant defense system. Proc Natl Acad Sci USA 1998, 95:2262-2266.

28. Klessig DF, Durner J, Noad R, Navarre DA, Wendehenne D, Kumar D, Zhou JM, Shah J, Zhang S, Kachroo P, Trifa Y, Pontier D, Lam E, Silva H: Nitric oxide and salicylic acid signaling in plant defense. Proc Natl Acad Sci USA 2000, 97:8849-8855

29. van Loon LC, Rep M, Pieterse CM: Significance of inducible defenserelated proteins in infected plants. Annu Rev Phytopathol 2006, 44:135-162.

30. Foster $\mathrm{JA}$, Gerton $\mathrm{GL}$ : Autoantigen 1 of the guinea pig sperm acrosome is the homologue of mouse Tpx-1 and human TPX1 and is a member of the cysteine-rich secretory protein (CRISP) family. Mol Reprod Dev 1996, 44:221-229.

31. Novina CD, Murray MF, Dykxhoorn DM, Beresford PJ, Riess J, Lee SK, Collman RG, Lieberman J, Shankar P, Sharp PA: siRNA-directed inhibition of HIV-1 infection. Nat Med 2002, 8:681-686.

32. Scheuring UJ, Sabzevari H, Corbeil J, Theofilopoulos AN: Differential expression profiles of apoptosis-affecting genes in HIV-infected cell lines and patient T cells. Aids 1999, 13:167-175.

33. Selliah N, Shackelford J, Wang JF, Traynor F, Yin J, Finkel TH: T cell signaling and apoptosis in HIV disease. Immunol Res 2003, 27:247-260.

34. Zheng L, Yang Y, Guocai L, Pauza CD, Salvato MS: HIV Tat protein increases $\mathrm{BCl}-2$ expression in monocytes which inhibits monocyte apoptosis induced by tumor necrosis factor-alpha-related apoptosisinduced ligand. Intervirology 2007, 50:224-228.

35. Fernandez Larrosa PN, Croci DO, Riva DA, Bibini M, Luzzi R, Saracco M, Mersich SE, Rabinovich GA, Martínez Peralta L: Apoptosis resistance in HIV1 persistently-infected cells is independent of active viral replication and involves modulation of the apoptotic mitochondrial pathway. Retrovirology 2008, 5:19.

36. Zhao C, Denison C, Huibregtse JM, Gygi S, Krug RM: Human ISG15 conjugation targets both IFN-induced and constitutively expressed proteins functioning in diverse cellular pathways. Proc Natl Acad Sci USA 2005, 102:10200-10205.

37. Moon HS, Yang JS: Role of HIV Vpr as a regulator of apoptosis and an effector on bystander cells. Mol Cells 2006, 21:7-20.

38. Perfettini $\mathrm{JL}$, Castedo M, Roumier T, Andreau K, Nardacci R, Piacentini M, Kroemer G: Mechanisms of apoptosis induction by the HIV-1 envelope. Cell Death Differ 2005, 12(Suppl 1):916-923. 
39. Milne TJ, Abbenante G, Tyndall JD, Halliday J, Lewis RJ: Isolation and characterization of a cone snail protease with homology to CRISP proteins of the pathogenesis-related protein superfamily. J Biol Chem 2003, 278:31105-31110

40. Serrano RL, Kuhn A, Hendricks A, Helms JB, Sinning I, Groves MR: Structural analysis of the human Golgi-associated plant pathogenesis related protein GAPR-1 implicates dimerization as a regulatory mechanism. $J$ Mol Biol 2004, 339:173-183.

41. Decroly E, Benjannet S, Savaria D, Seidah NG: Comparative functional role of PC7 and furin in the processing of the HIV envelope glycoprotein gp160. FEBS Lett 1997, 405:68-72.

42. Tyagi M, Rusnati M, Presta M, Giacca M: Internalization of HIV-1 tat requires cell surface heparan sulfate proteoglycans. J Biol Chem 2001, 276:3254-3261.

43. Teixe T, Nieto-Blanco P, Vilella R, Engel P, Reina M, Espel E: Syndecan-2 and -4 expressed on activated primary human CD4(+) lymphocytes can regulate T cell activation. Mol Immunol 2008, 45:2905-19.

44. Yu G, Shen FS, Sturch S, Aquino A, Glazer Rl, Felsted RL: Regulation of HIV1 gag protein subcellular targeting by protein kinase C. J Biol Chem 1995, 270:4792-4796.

45. Cartier C, Hemonnot B, Gay B, Bardy M, Sanchiz C, Devaux C, Briant L: Active cAMP-dependent protein kinase incorporated within highly purified HIV-1 particles is required for viral infectivity and interacts with viral capsid protein. J Biol Chem 2003, 278:35211-35219.

46. Jakobovits A, Rosenthal A, Capon DJ: Trans-activation of HIV-1 LTRdirected gene expression by tat requires protein kinase C. Embo J 1990 9:1165-1170.

47. Kino T, Slobodskaya O, Pavlakis GN, Chrousos GP: Nuclear receptor coactivator 160 proteins enhance the HIV-1 long terminal repeat promoter by bridging promoter-bound factors and the Tat-P-TEFb complex. J Biol Chem 2002, 277:2396-2405.

48. Nguyen $\mathrm{DH}$, Hildreth JE: Evidence for budding of human immunodeficiency virus type 1 selectively from glycolipid-enriched membrane lipid rafts. J Virol 2000, 74:3264-3272.

49. Charneau P, Alizon M, Clavel F: A second origin of DNA plus-strand synthesis is required for optimal human immunodeficiency virus replication. J Virol 1992, 66:2814-2820.

50. Osborne $R$, Mason $H$, Browning $M$, Mitchell $R$, Jarrett $W$ : A sensitive assay for detection and measurement of neutralising antibody to human immunodeficiency virus. J Virol Methods 1992, 39:15-26.

51. Scheuring UJ, Pfeifer H, Wassmann B, Bruck P, Atta J, Petershofen EK, Gehrke B, Gschaidmeier H, Hoelzer D, Ottmann OG: Early minimal residual disease (MRD) analysis during treatment of Philadelphia chromosome/ Bcr-Abl-positive acute lymphoblastic leukemia with the Abl-tyrosine kinase inhibitor imatinib (STI571). Blood 2003, 101:85-90.

doi:10.1186/1742-4690-7-26

Cite this article as: Capalbo et al.: Inhibition of HIV-1 replication by small interfering RNAs directed against Glioma Pathogenesis Related Protein (GliPR) expression. Retrovirology 2010 7:26.

\section{Submit your next manuscript to BioMed Central and take full advantage of:}

- Convenient online submission

- Thorough peer review

- No space constraints or color figure charges

- Immediate publication on acceptance

- Inclusion in PubMed, CAS, Scopus and Google Scholar

- Research which is freely available for redistribution

Submit your manuscript at www.biomedcentral.com/submit
Ciomed Central 